\title{
A Critical Review of Capital Structure Theories
}

\author{
Syed Muhammad Javed Iqbal1,2, *Saqib Muneer ${ }^{2}$, Agha Jahanzeb², Saif-ur-Rehman² \\ ${ }^{1}$ Department of Commerce, the Islamia University of Bahawalpur, Pakistan \\ ${ }^{2}$ Faculty of Management and Human Resource Development (FPPSM) \\ University Technology Malaysia, Malaysia \\ *saqibmuneer85@gmail.com
}

\begin{abstract}
The purpose of this paper is to scrutinize and appreciate the theories of capital structure starting from theory of Miller and Modigliani (1958) of capital structure, which is also known as irrelevance theory of capital structure and also including theory like pecking order theory, trade off theory, market timing theory and agency cost theory. In addition, authors have tried to explain the theories and their contradiction with each other in detail. This paper will be an addition to understand the theories of capital structure.
\end{abstract}

Keywords: Capital structure theories, capital structure, trade off theory, debt, equity, leverage, agency cost

\section{Introduction}

In capital structure theories, the theory of Modigliani and Miller "irrelevance theory of capital structure" presented in 1958 has significant importance and has captured interest of finance managers, practitioners and economists. The "irrelevance model" is working under the assumption of perfect capital markets and that deviate from three major theories of capital structure. These four major theories are

- Trade-off theory

- Pecking order theory

- Market Timing Theory of Capital Structure

- Agency Cost (Theory)

The trade-off theory is the trading-off the benefits of the firm with cost of debt and equity. Under trade-off theory, the firm tries to find "optimal" capital structure to have a best combination of debt and equity. The other costs like taxes, costs of agency and bankruptcy costs are also considered while deciding the trade-offs. The next theory is about "pecking order theory" given by Myers and Myers and Mailuf (1984) which states that firms adopt a strategy known as financing hierarchy to minimize the irregularity of information between firm's managers and outside stake/stockholders. Baker and Wurgler presented the last theory in 2002 known as "market timing theory of capital structure". Market timing is about the issuance of shares. It states that firms issues new shares in the market when they assume that the market price of the share is overvalued and firm repurchase its shares which is also termed as "treasury stock" when the firm perceive that the market price of the share is undervalued. This theory states that existing capital structure is the cumulative result of the firm's past experience, which it had attempted time to time under equity market. The behavior of market timinghas already been well established by other researchers but Baker and Wurgler has presented their theory by proving that market timing influence on the capital structure of the firm is regular and continuous. In today's economic world, agency cost has great importance since it is related to the cost of debt and equity as well.

\section{The Theorem of Modigliani and Miller}

It is said that Modigliani and Miller has established the basis of modern finance in 1958 because before them there was no generally accepted theory of capital structure. They argued that capital structure has irrelevance proposition. They started with assumptions that a firm has

- Particular set of expected cash flows. 
- It divides the cash flows among the investors when it chooses a certain combination of debt and equity for purchasing of assets

- Firms and investors have equal opportunity to access the financial markets

- The investors can create any leverage according to their own

Therefore, the conclusion is that firm can leverage that has no effect of the market value of the firm. Their theory got some of its followers as well as some controversies. However, their theory needs some certain circumstances otherwise, it cannot run. Now there are two different types of capital irrelevance propositions. Classical theory says that firm can create its own leverage irrelevance of the investors rather Modigliani and Miller. In addition to MM Hirshleifer (1966) and Stiglitz (1969) made approach important contributions. Second contribution to irrelevance theory of proposition was that "given a firm's investment policy, the dividend payout it chooses to follow will affect neither the current price of its shares nor the total return to its shareholders" (Miller and Modigliani, 1961). Simply stating, neither dividend policy nor capital structure matters in perfect market. As stated above, in 1958 much research was conducted to disprove the irrelevance theory of MM because it works under certain circumstances otherwise it fails. Usually the common elements considered under capital structure model are: taxes, agency cost, bankruptcy cost, transaction costs, lack of separation of financing and operations, time to market, market value of stock, and effect on client etc. The other models against MM approach use some of the different element of above list. So many other theories are available but this is beyond the capability of the author and paper to cover in them in one text. No doubt, the other theories also contributed to the capital structure theorem but it so much difficult to test and authenticate any of them. MM theorem may have some weaknesses but they also cannot be fully ignored or rejected.

\section{The Trade-Off Theory}

Trade-off theory is also one of the important theories of capital structure modeling. Trade-off here means the Trade-off benefits and costs of the firm. The firm decides to find the set of investment(s), which is better than the others are. More conservatively sometime marginal costs and marginal benefits are compared with each solution depending upon the preference of the stakeholders. The trade-off theory was seriously taken under consideration after the debate on the theorem of Modigliani-Miller. When income tax of corporation was added to the original irrelevance, it created debt benefit and it provided a shield to earnings from taxes. Since the trade-off of cost of debt is linear. This Myers' definition kept several aspects of discussion. First one was that target cannot be directly decided it may be the result of imputed evidence. However, different papers have presented this idea in different ways. Secondly, amount of tax is not as easy as computed under this theory. A useful review of literature on tax effects are provided by Graham in (2003). Thirdly, the bankruptcy costs are also considered as dead costs as discussed by Haugen and Senbet (1978); Fama and French (1998), Kemsley, and Nissim (2002). Next consideration is cost of transactions. It must also be treated as adjustment will be made gradually not at once. As a result, longer the adjustment time greater the marginal costs Leary and Roberts (2005). There are further two theories of trade-off one is static trade-off theory and other is dynamic trade-off theory.

Static trade off theory: Static trade-off theory assumes that there is optimal capital structure of the firm. Means under ideal situation the costs and benefits of debt and equity are calculated. By doing this firms gets the benefit of tax shield and on the other hand it has drawback that when a firm has too much debt it can create future serious damage to the firm capital structure. Therefore, in simple world it provides tax benefit as well as serious financial distress in case of relying on too much debt. Another element to be considered is agency cost. Agency cost may be base of different conflicts of interest among different stakeholders of the firm because of ex post-unbalanced information e.g. Jensen and Meckling (1976) and Jensen (1986). The discussion ends with a conclusion that agency cost and tax are considered under static trade-off theory but the actual leverage deviate from the optimal capital structure. However, a firm tries to bring its capital structure near to optimal level to get the benefit of the theory.

Dynamic trade-off Theory: Dynamic trade off theory considers the element of time, which is usually ignored in single-period models. This dynamic theory leads to the correct decision of finance because it considers financing margin and anticipation for coming period. Because some of the firms expect to pay some debts or 
funds while the others may need to rise fund. The needed funds may be collected in shape of debt or equity. In addition, generally firms like to make the combination of both. The first dynamic model was presented by Kane et al. (1984) AND Brenan and Schwartz (1984). Both models considered the effect of uncertainty, taxes, and bankruptcy cost but ignored transaction costs. Since the firms immediately response to imbalance of debt and equity and maintain the tax benefits in shape of high level of debt. Goldstein et al. (2001) firms with low leverage currently have option to increase its leverage tomorrow. Under this assumption, the firms having low leverage today will face the threat of high financing in the future. Strebulaev (2007) presented a model quite similar to that of Goldstein et al. (2001) and Fischer et al. (1989). Ultimately, most firms cannot adopt the optimal level of debts mostly. Firms less response to short run equity ups and downs more the long run values changes. Some of the ideas are accepted under dynamic model. The optimal choice today can also lead to optimal choice in the future. In simple words the firm can have optimal level today can raise more funds and can pay them out in future. In addition, dynamic model is now mostly accepted now as compared to previous years. The work has already been altered the understanding of role of profits, mean reversion and role of retained-earning.

\section{The Pecking Order Theory}

The theory of Pecking Order is not so much taken optimally in the capital structure, as the beginning point, but declare the fact empirically proved that 208 firms prefer internal sources of finance such as retained earnings of the firms or excess liquid assets instead of eternal finance. Firms are not eager in external finance if they do not have sufficient internal finance. If external funds are inevitable then the firms like to make choice among those external sources of funds, which has less cost of capital as well as cost of uneven information. This asymmetric information cost originally refer to a term known as "lemon premium" (akerlof, 1970) that external investors asset so much care while financing an average firm due to risk of their failure in the market. The pecking order theory suggests that internal sources of funds produce less risk of finance and share finance. In the model of Myers and Mailuf (1984), it is argued that when managers issue equity securities instead of riskless securities the investors discounts the firm's stock price rationally. Therefore, managers like to avoid the issuance of equity finance due the discount by external investors. According to Myers and Mailuf the managers will like to follow the pecking order theory, that they like to search for internal finance first and then to external debt and in the last issuance of equity. If the firm's is not in a strong position then it likes to retain some portion of profit to avoid the external funds. As a measure of investment opportunity, the pecking order theory concerns the market to book ration. Having this interpretation in mind the Myers (1984), Fama, and French (2000) both note that concurrent relationship between capital structure and market to book ratio is hard to settle with the static model of pecking order theory. Repetition of the static version of pecking order theory also proposes that during the high investment opportunities will tend to increase the leverage in the direction of the debt capacity. Both theories the theory of pecking order and trade of theory both are empirically supported when it was tested to see whether which one is better predictor of proposed capital structure it was found that both theories support the capital structure of the firm (Shyam -Sunder and Myers, 1999; Fama and French, 2002)

\section{The Market timing theory}

Market timing theory in the capital structure theory declares that the firm issues the equity securities when they perceived that their stocks are overvalued and buy back it when they find that shares are undervalued. This continuous fluctuation in the prices of stocks of firms affects the capital structure of firm. Equity market time theory has two versions of capital structure dynamics. The assumption of first version is that economic agents should be rational. To avoid asymmetric problem the firm may issue the shares directly to the potential investor after the release of positive information about the company. This can reduce the information gap between management of firm and stockholders. It may increase the price of share when there is regular sharing of information between the above two. The assumption of second theory is that economic agent should be irrational (Baker and Wurgler, 2002). Due to this irrational behavior, the prices of stock vary and mispriced. Manager issue the securities irrationally when prices are low and purchase irrationally when prices are up. The second theory also proposes that information is not correct. The main point is that managers think themselves that they have complete information about the time of the market. Graham and Harvey (2001) showed that managers admitted that while issuing or buying back of the firm's 
stock time to market is important consideration for them. In addition, there is support by study that managers believe that they can time the market but actually, they cannot distinguish between mispricing and asymmetric information about the company. There is evidence from Baker and Wurgler (2002) that market timing of equity securities has insistent effect on the firm's capital structure. They argue by defining the market timing measure as external capital weighted average needs in past few years, where the weights used are market to book values of the firms. They showed that changes in the leverage of the firm are related positively and strongly to the measure of market timing, and their conclusion was that capital structure of the firm is the result of previous collective attempts to time the equity market.

\section{Agency Cost Theory}

In constraints on capital structure decisions, agency cost is one of the major constraints, which is crucial for management, shareholders, employees and creditors. Fundamentally, an agency problem arises due to divergences of interest of stakeholders (e.g. managers, employees and creditors) with shareholders. Jensen \& Meckling (1976) presented the agency theory by focusing on the management and shareholder. In capital structure decisions, agency cost can be arises in three ways; one is free cash flow, second is assets substitutions effect and third is problem of debt overhang (Wiki, 2012). In assets substitutions effect, managers take a risk by investing into some very risky project. On the success of project, all the profit goes to shareholders and in case of failure, all the burden put on the shoulders of debt-holders. In debt overhang problem, debt is costly and all the gain from project will be accrue by debt-holder instead of shareholders. In this situation, managers accept the negative NPV project rather than positive NPV projects. In the case of free cash flow, manager destroys organization value by investing profit into unnecessary projects (e.g. parks building, empire building etc.) instead of giving back that free cash flow to investors. The main argument of agency theory is that investment decisions are related and have strong impact on capital structure decisions (Jensen \& Meckling, 1976).

\section{Conclusion}

Theorem of Modigliani and Miller (1958) started a debate on basic nature of debt and equity, when we talking about the capital structure of a firm. Transactions among the various suppliers of finance generate the capital structure of a firm. MM (1958) argued that in perfect capital markets, cost of various financing sources have no independent impact; therefore, firm cannot gain any extra profit by choosing any finance source. However, sources of finance clearly affected by some major factors like taxes, asymmetry information and agency problems (costs). Interpretations of these factors are differed in various theories of capital structure since these are not designed to be general (some focus on cost and other focus on benefits of various sources of financing). In case of trade-off theory, usage of debt in capital structure can effect by bankruptcy and taxes. Pecking order theory argued that unpleasant selection of debt proportion is account in capital structure. According to the active or current research on these theories, these theories have some weak parts in them. On the other hand, market-timing theory disputed that there is no optimal capital structure; therefore, capital structure is an outcome of various decision, which have done over a time. According to the agency cost theory of capital structure, proportions of debt and equity in capital structure have some costs, which have strong impact on the selection of capital structure. It can be said that market-timing theory explained the capital structure issues more clearly than other theories.

\section{References}

Akerlof, G. A. (1970). The market for emons: Quality uncertainty and the market mechanism. Quarterly Journal of Economics, 84(3), 488-500.

Alti, A. (2003). How persistent is the impact of market timing on capital structure? Working paper.

Atkeson, A. \& Cole, H. (2005). A dynamic theory of optimal capital structure and executive compensation, working paper, NBER 11083.

Baker, M. \& Wurgler, J. (2002). Market timing and capital structure. Journal of Finance, 57(2).

Brennan, M. J. \& Schwartz, E. S. (1984). Optimal financial policy and firm valuation. Journal of Finance, 39(1).

Dittmar, A. (2004). Capital structure in corporate spinoffs. Journal of Business, 77(2). 
Fama, E. F. \& French, K. R. (1998). Value versus Growth: The International Evidence. Journal of Finance, 53, 1975-1999.

Fama, E. \& French, K. R. (2002). Testing trade-off and pecking order predictions about dividends and debt. Review of Financial Studies, 15(1), 312-320.

Fischer, E. O., Heinkel, R. \& Zechner, J. (1989). Dynamic Capital Structure Choice: Theory and Evidence. Journal of Finance, 44, 19-40.

Goldstein, R., Ju, N. \& Leland, H. (2001). An ebit-based model of dynamic capital structure. Journal of Business, 74, 483-512.

Graham, J. R. \& Harvey, C. (2001). The theory and practice of corporate finance: evidence from the field. Journal of Financial Economics, 60, 187-243.

Graham, L. (2003). Writing journals: an investigation. Reading literacy and language, 37(1), 39-42.

Harris, M. \& Raviv, A. (1991). The theory of capital structure. Journal of Finance, 46, 297- 356.

Haugen, R. A. \& Senbet, L. W. (1978). The insignificance of bankruptcy costs to the theory of optimal capital structure. Journal of Finance, 33, 383-393.

Hirshleifer, J. (1966). Investment decision under uncertainty: Applications of the state preference approach. Quarterly Journal of Economics, 80, 252-277.

Jensen, M. C. \& Meckling, W. H. (1976). Theory of the firm: managerial behavior, agency costs and ownership structure. Journal of Financial Economics, 3, 305-360.

Jensen, M. C. (1986). Agency Costs of Free Cash Flow, Corporate Finance, and Takeovers. American Economic Review, 76(2), 323-329.

Kane, A., Marcus, A. J. \& McDonald, R. L. (1984). How big is the Tax Advantage to Debt? Journal of Finance, 39, 841-53.

Kemsley, D. \& Nissim, D. (2002). Valuation of the debt tax shield. Journal of Finance, 57(5), 2045-2073.

Leary, M. T. \& Roberts, M. R. (2005). Do firms rebalance their capital structures? Journal of Finance, 60(1).

Modigliani, F. \& Miller, M. H. (1958). The cost of capital, corporate finance and the theory of investment. American Economic Review, 48, 261-297.

Modigliani, F. \& Miller, M. H. (1963). Corporate income taxes and the cost of capital: A correction. American Economic Review, 53, 433-443.

Murray, Z. F. \& VidhanK, G. (2007). Trade-off and Pecking Order Theories of Debt, working paper, NBER 16180.

Myers, S. C. \& Majluf, N. S. (1984). Corporate financing and investment decisions when firms have information those investors do not have. Journal of Financial Economics, 13, 187-221.

Shyam-Sundler, L. \& Myers, S. C. (1999). Testing Static Tradeoff against Pecking Order Models of Capital Structure. Journal of Financial Economics, 51, 219-44.

Strebulaev, A. I. (2007). Do Tests of Capital Structure Theory Mean What They Say? Journal of Finance, American Finance Association, 62(4), 1747-1787.

Stiglitz, J. E. (1969). A re-examination of the Modigliani-Miller Theorem. American Economic Review, 59, 784793. 